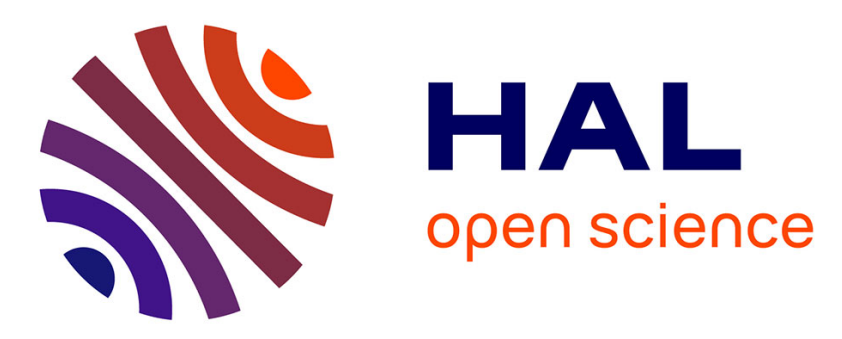

\title{
Analysis of chemically synthesized oleoylethanolamide by gas-liquid chromatography
}

Clémentine Thabuis, Delphine Tissot-Favre, Jean-Baptiste Bezelgues, Jean-Charles Martin, Cristina Cruz-Hernandez, Fabiola Dionisi, Frédéric Destaillats

\section{To cite this version:}

Clémentine Thabuis, Delphine Tissot-Favre, Jean-Baptiste Bezelgues, Jean-Charles Martin, Cristina Cruz-Hernandez, et al.. Analysis of chemically synthesized oleoylethanolamide by gas-liquid chromatography. Journal of Chromatography A, 2008, 1202 (2), pp.216-219. 10.1016/j.chroma.2008.07.008 . hal-02658715

\section{HAL Id: hal-02658715 https://hal.inrae.fr/hal-02658715}

Submitted on 30 May 2020

HAL is a multi-disciplinary open access archive for the deposit and dissemination of scientific research documents, whether they are published or not. The documents may come from teaching and research institutions in France or abroad, or from public or private research centers.
L'archive ouverte pluridisciplinaire HAL, est destinée au dépôt et à la diffusion de documents scientifiques de niveau recherche, publiés ou non, émanant des établissements d'enseignement et de recherche français ou étrangers, des laboratoires publics ou privés. 


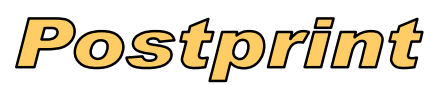

Version définitive du manuscrit publié dans / Final version of the manuscript

published in : Journal of Chromatography A, vol.1202, no.2, 216-219

1 Analysis of Chemically Synthesized Oleoylethanolamide by Gas-

\section{Liquid Chromatography}

3

4 Clémentine Thabuis ${ }^{1}$, Delphine Tissot-Favre ${ }^{2}$, Jean-Baptiste Bezelgues ${ }^{2}$, Jean-Charles Martin ${ }^{1}$ Cristina Cruz-Hernandez ${ }^{2}$, Fabiola Dionisi ${ }^{2}$, and Frédéric Destaillats ${ }^{2, *}$

6

${ }^{1}$ INRA, UMR1260 «Nutriments Lipidiques et Prévention des Maladies Métaboliques», Marseille, F-13385 France ; INSERM, U476, Marseille, F-13385

9 France ; Univ Aix-Marseille 1, Univ Aix-Marseille 2, Faculté de Médecine, IPHM-IFR 125, Marseille, F-13385 France; (Switzerland)

13

14 Correspondence should be addressed:

Nestlé Research Center

Vers-chez-les-Blanc, P.O.Box 44

17

CH - 1000 LAUSANNE 26, Switzerland

$18 \quad$ E-mail: frederic.destaillats@rdls.nestle.com

Tel.:+41217858937

Fax: +41217858553

\section{Running title: GLC ANALYSIS OF OLEOYLETHANOLAMIDE}

23 Key words: Fatty acid ethanolamide, oleoylethanolamide, oxazoline, gas-liquid 24 chromatography 


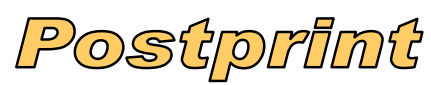

Version définitive du manuscrit publié dans / Final version of the manuscript published in : Journal of Chromatography A, vol.1202, no.2, 216-219

25 ABSTRACT: OEA is known to potentially have beneficial biological effects on weight 26 management by controlling food intake and activating lipid catabolism. In biological fluids, 27 OEA and other endogenously biosynthesized FAEAs, are usually analyzed by tandem liquid28 chromatography mass-spectrometry (LC-MS). The present study provides analytical method 29 to routinely assess the quality of OEA prepared for biological studies by gas-liquid 30 chromatography (GLC). The preparation of OEA for biomedical studies can be performed by $31 \mathrm{~N}$-acylation of oleic acid/esters or using oleoyl chloride. In the present study, OEA was 32 prepared by transamidation of triolein. The analysis of the synthesized OEA has been 33 performed by gas-liquid chromatography of its trimethylsilylether (TMS) derivatives. Free 34 OEA cannot be analyzed as such because dehydration of the ethanolamide moiety promptly 35 happens in the GLC injection. This thermal degradation reaction gives rise to the formation of 36 an oxazoline derivative. The TMS moiety prevents the reaction and the structure of the 37 formed derivative was assessed by mass-spectrometry. We show here, that OEA prepared for 38 biological studies can be routinely analyzed by GLC after TMS derivative preparation. 


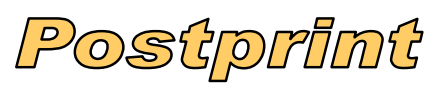

Version définitive du manuscrit publié dans / Final version of the manuscript published in : Journal of Chromatography A, vol.1202, no.2, 216-219

\section{INTRODUCTION}

Fatty acid ethanolamides (FAEA) belong to a family of lipids naturally found in both plant and animal tissues. Moreover these fatty acid derivatives appear to have biological properties. Indeed palmitoylethanolamide (derived from palmitic acid) have antinociceptive and anti-inflammatory properties [1]. Among this family, anandamide (derived from arachidonic acid) has been of great interest. In the last decade, it was discovered that anandamide is an endogenous ligand for cannabinoid receptor subtype 1 (CB1). Activating CB1, anandamide increases food intake. Another interesting fatty acid ethanolamides is oleoylethanolamide (OEA), formed from oleic acid and phosphatidylethanolamine in the brain and in the intestine[2-5]. Biological function of OEA such as anorexigenic or body fat loss properties have been extensively studied over the past decade [5-6]. This molecule is naturally present at low concentrations in food products such as cocoa powder (up to $2 \mathrm{mg} / \mathrm{g}$ ), oatmeal or nuts [7]. The OEA biological function is to regulate food intake via a synthesis/degradation balance, which occurs mainly in the enterocytes (brush border) $[3,8]$. The biological mechanism of action including non-genomic effect mediated through peroxisome proliferator-activated receptor alpha (PPAR- $\alpha$ ) [9] and transient receptor potential vanilloid type 1 (TRPV1) receptor are discussed [10,11].

LC-based methodologies have been developed to quantify OEA and other endogenously formed FAEAs in biological fluids and tissues [8]. The level of OEA in plasma or other fluids, such as cerebrospinal fluid, is very low (around $10 \mathrm{pmol} / \mathrm{ml}$ ), but recent development allowed to reach a quantification limit below 1 pmol by LC-MS/MS using electrospray ionization in the positive mode and silver cation coordination [12]. Quantification can also be performed using single stage LC-MS as shown by Giuffrida et al. [13], or by RMN analysis [14]. However, LC-MS is not a routine method to assess the quality of OEA preparation used in biological experiments. 


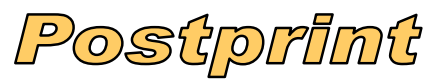

Version définitive du manuscrit publié dans / Final version of the manuscript published in : Journal of Chromatography A, vol.1202, no.2, 216-219

OEA have been synthesized from triolein by our research group to conduct chronic oral supplementation in further studies. The objective of the present study was to develop a method to assess the quality of OEA preparation produced for biomedical studies.

\section{MATERIALS AND METHODS}

2.1. Chemical and reagents. Ethanolamine (99\% purity), trimethylsilylchlorosilane (TMCS) and N,O-Bis(trimethylsilyl)trifluoroacetamide (BSTFA) was obtained from SigmaAldricht (Saint Louis, USA). Triolein was obtained from Nu Check Prep (Elysian, USA). Sodium sulfate decahydrate was obtained from Riedel-de Haën (Hanover, Germany).

2.2. Synthesis of oleoylethanolamide(OEA) from triolein. OEA was prepared as described by Roe et al. [15] with slight modification. Triolein $(1 \mathrm{~g})$ and ethanolamine $(0.5 \mathrm{~g})$ were stirred under inert conditions in a test tube and the mixture was heated at $170^{\circ} \mathrm{C}$ for 30 min. After cooling to room temperature, the residue was dissolved in hexane $(25 \mathrm{~mL})$ and washed with warm sodium sulfate $(10 \%$ aquous solution, $200 \mathrm{ml})$ in a funnel. The organic phase was washed another time with the same solution. The solvent was removed and OEA has been stored at $4^{\circ} \mathrm{C}$ under argon.

2.3. Preparation of trimethylsilylether (TMS) derivatives. TMS derivative was prepared following the standard AOCS method Cd 11b-91 [16]. Briefly, OEA (10 mg), trimethylchlorosilane $(200 \mu \mathrm{L})$ and BSTFA were stirred in a test tubes heated at $70^{\circ} \mathrm{C}$ for 20 min. After, cooling to room temperature OEA TMS derivative was diluted in hexane at 0.1 $\mathrm{mg} / \mathrm{mL}$.

2.4. Gas-liquid chromatography analysis. Analyses of OEA TMS derivative and free (OEA $0.1 \mathrm{mg} / \mathrm{mL})$ were performed by GLC using a DB-5HT capillary column (15 m x 0.25 mm i.d., film thickness $0.10 \mu \mathrm{m}$; J\&W, Palo Alto, USA). Split injection (50:1) and flameionization detection (FID) were achieved at $320^{\circ} \mathrm{C}$ and $400^{\circ} \mathrm{C}$, respectively. Oven temperature 
POSE์P

Version définitive du manuscrit publié dans / Final version of the manuscript published in : Journal of Chromatography A, vol.1202, no.2, 216-219

88 programming was $150^{\circ} \mathrm{C}$, increased to $300^{\circ} \mathrm{C}$ at $20^{\circ} \mathrm{C} \mathrm{min}^{-1}$, and then to $380^{\circ} \mathrm{C}$ for 2 min at $8910^{\circ} \mathrm{C} \min ^{-1}$. Carrier gas (H2) was used in constant flow mode at $2 \mathrm{ml} \cdot \mathrm{min}^{-1}$.

2.5. Gas-chromatography mass-spectrometry (GC-MS) analysis. OEA was analyzed by GC-MS as its TMS derivative on a 6890 Series II gas-chromatograph (Agilent, Palo Alto, CA) attached to a 5973N selective quadrupole mass detector (Agilent Technologies, Palo Alto, CA)] under an ionization voltage of $70 \mathrm{eV}$, and connected to a computer with a HewlettPackard ChemStation. The injector, in split mode (25:1), and the interface temperatures were maintained at $250^{\circ} \mathrm{C}$ and $280^{\circ} \mathrm{C}$, respectively. Helium was used as carrier gas under constant flow rate $(1.8 \mathrm{~mL}$ min-1). GC separation was performed on a DB-1 capillary column (30 m x $0.25 \mathrm{~mm}$ i.d., film thickness $0.25 \mu \mathrm{m}$; J\&W, Palo Alto CA). Oven temperature programming was $100^{\circ} \mathrm{C}$, increased to $270^{\circ} \mathrm{C}$ at $50^{\circ} \mathrm{C} \mathrm{m^{-1 }}$, isothermal for $12 \mathrm{~min}$. Electron impact mass spectra were recorded in the $100-400 \mathrm{u}$ mass range. purified fatty acids or methyl esters derived from vegetable oils and or animal fats. FAEAs such as OEA can be produced by a Schotten-Bauman reaction [14] where a fatty acyl chloride is reacted with ethanolamine or according to Roe et al. [15] starting from fatty acid ester such as triacylglycerol. In the present study, we used triolein as a starting material (see Figure 1). The reaction is complete after $30 \mathrm{~min}$ and need to be performed at $170^{\circ} \mathrm{C}$. The GLC method described utilizes a wide range of temperature starting from $60^{\circ} \mathrm{C}$ to $380^{\circ} \mathrm{C}$ and can therefore 108 be used to analyze glycerides or fatty acids (results not shown). Therefore, the given 109 conditions can be used to calculate the yield of the reaction. However, using the described 110 parameters used for the synthesis of OEA, remaining traces of triolein, diolein or monoolein 111 were not detected. 


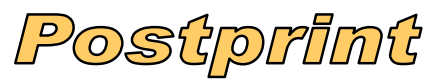

Version définitive du manuscrit publié dans / Final version of the manuscript published in : Journal of Chromatography A, vol.1202, no.2, 216-219

Excessive temperature (i.e. $>200^{\circ} \mathrm{C}$ ) can lead to the formation of a degradation

113 product. This reaction also happens when OEA is analyzed as a free compound by GLC. The degradation product is less polar and elutes before free OEA (see Figure 2A). The exposure to high temperature (i.e. in the injection port) catalyses the self-condensation of the ethanolamide moiety giving rise to the formation of an oxazoline derivative as described in

Figure 3. This type of reaction is routinely used to prepare dimethyloxazoline derivatives from fatty acid esters and 2-aminopropanol for mass-spectrometry analysis of fatty acids [17]. In addition, this reaction can be performed using trifluoroacetic anhydride and mild 120 temperature as described by Kuklev and Smith [18]

Free OEA needs therefore to be stabilized prior to GLC analysis. TMS derivative has been prepared and analyzed under the same analytical conditions (see Figure 2B). The derivatization reaction was performed according to the AOCS method Cd 11b-91 using TMCS and BSTFA [16]. The structure of the obtained derivative was analyzed by GC-MS. The typical mass-spectrum of OEA as TMS derivative is shown in Figure 4. The mass spectrum is characterized by an intense molecular ion at $397.2 \mathrm{amu}$ and a fragment ion at $382.2 \mathrm{amu}$ that corresponds to a loss of a methyl group of the TMS moiety. Only a trace amount degradation product represented less than $1 \%$ were detected by GC-MS and a typical

129 GLC-FID chromatogram is shown in Figure 2B. This result shows that the derivatization of OEA can effectively be performed using standard procedure and that the obtained derivative 131 is more stable under thermal condition.

\section{CONCLUSION}

The analysis of OEA by GLC is a convenient technique to analyze the composition of 134 OEA preparation. However, OEA need to be derivatized prior GLC analysis due to its poor 135 thermal stability. The formation of the oxazoline derivative can be prevented by preparing 136 TMS derivative that stabilizes the ethanolamide moiety. This method can be routinely used to 


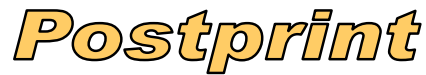

Version définitive du manuscrit publié dans / Final version of the manuscript published in : Journal of Chromatography A, vol.1202, no.2, 216-219

assess the quality of the synthetic preparation produced for biomedical studies. For quantitative analysis of complex FAEA mixtures in biological fluids, the basic principle, described in the present study, can certainly be applied. However, the chromatographic condition and the quantification procedure need to be developed.

\section{REFERENCES}

[1] D.M. Lambert, S. Vandevoorde, K.O. Jonsson, C.J. Fowler, Curr Med Chem 9 (2002) $663-74$.

[2] G. Astarita, B.C. Rourke, J.B. Andersen, J. Fu, J.H. Kim, A.F. Bennet, J.W. Hicks, D. Piomelli,. Am J Physiol Regul Integr Comp Physiol 290 (2006) 1407-12.

[3] J. Fu, G. Astarita, S. Gaetani, J. Kim, B.F. Cravatt, K. Mackie, D. Piomelli, J Biol Chem 282 (2007) 1518-28.

[4] J. LoVerme, M. Guzman, S. Gaetani, D. Pomelli, J Biol Chem 281 (2006) 22815-8.

[5] F. Rodriguez de Fonseca, M. Navarro, R. Gomez, L. Escuredo, F. Nava, J. Fu, E. MurilloRodriguez, A. Giuffrida, J. LoVerme, S. Gaetani, S. Kathuria, C. Gall, D. Piomelli, Nature 414 (2001) 209-12.

[6] V. Di Marzo, N. Sepe, L. De Petrocellis, A. Berger, G. Crozier, E. Fride, R. Mechoulam, Nature 396 (1998) 636-7.

[7] G. Crozier Willi, A. Berger, V. Di Marzo. T. Bisogno, L. De Petrocellis, E. Fride, R. Mechoulam, Nestle Nutr Workshop Ser Clin Perform

Programme 5 (2001) 169-84.

[8] J. Fu, S. Gaetani, F. Oveisi, J. LoVerme, A. Serrano, F. Rodriguez de Fonseca, A. Rosengarth, H. Luecke, B. Di Giacomo, G. Tarzia, D. Piomelli, Nature 425 (2003) 90-3.

[9] J. Fu, F. Oveisi, S. Gaetani et al. , Neuropharmacology 48 (2005) 1147-53.

[10] G.P. Ahern, J Biol Chem 278 (2003) 30429-34.

[11] R. Almasi, E. Szoke, K. Bolcskei, A. Varga, Z. Riedl, Z. Sandor, J. Szolcsanyi, G. Petho, Life Sci 82 (2008) 644-51.

[12] P.D. Cani, M.L. Montoya, A.M. Neyrinck, N.M. Delzenne, D.M. Lambert, Br J Nutr 92 (2004) 757-61. 


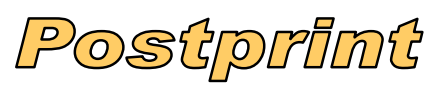

Version définitive du manuscrit publié dans / Final version of the manuscript published in : Journal of Chromatography A, vol.1202, no.2, 216-219

165 [13] A. Giuffrida, F. Rodriguez de Fonseca, D. Piomelli, Anal Biochem 280 (2000) 87-93.

166 [14] G. Astarita, B. Di Giacomo, S. Gaetani, F. Oveisi, T.R. Compton, S. Rivara, G. Tarzia, 167 M. Mor, D. Piomelli, J Pharmacol Exp Ther 318 (2006) 563-70.

168 [15] E.T. Roe, J.M. Stutzman, J.T. Scanlan, D. Swern, J. Am. Oil Chem. Soc. (1952) 29:1816922.

170 [16] D. Firestone, editor. In Official Methods and Recommended Practices of the AOCS,

171 AOCS Press, Champaign, Recommended Practice Cd11c-93 (1997).

172 [17] J.L Garrido, I. Medina, J. Chromatogr. 673 (1994) 101-105.

173 [18] D.V. Kuklev, W.L. Smith, J. Lipid Res. 44 (2003) 1060-1066. 


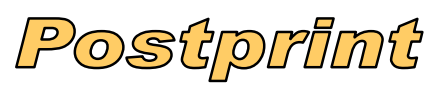

Version définitive du manuscrit publié dans / Final version of the manuscript published in : Journal of Chromatography A, vol.1202, no.2, 216-219

174 Legend of Figures.

175 Figure 1. Preparation of oleoylethanolamide (OEA) by transamidation of triolein.

176 Figure 2. Gas-liquid chromatography analysis of (A) free oleoylethanolamide (OEA) or (B)

177 as its trimethylsilylether (TMS) derivative.

178 Figure 3. Formation of an oxazoline derivative of oleoylethanolamide (OEA) thermal 179 degradation of at high temperature $\left(>200^{\circ} \mathrm{C}\right)$.

180 Figure 4. Mass-spectrum of oleoylethanolamide (OEA) as trimethylsilylether (TMS)

181 derivative. Ionization performed by electron impact at $70 \mathrm{eV}$. 


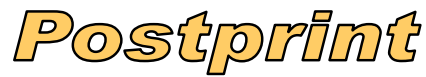

Version définitive du manuscrit publié dans / Final version of the manuscript published in : Journal of Chromatography A, vol.1202, no.2, 216-219

Fig 1.

183

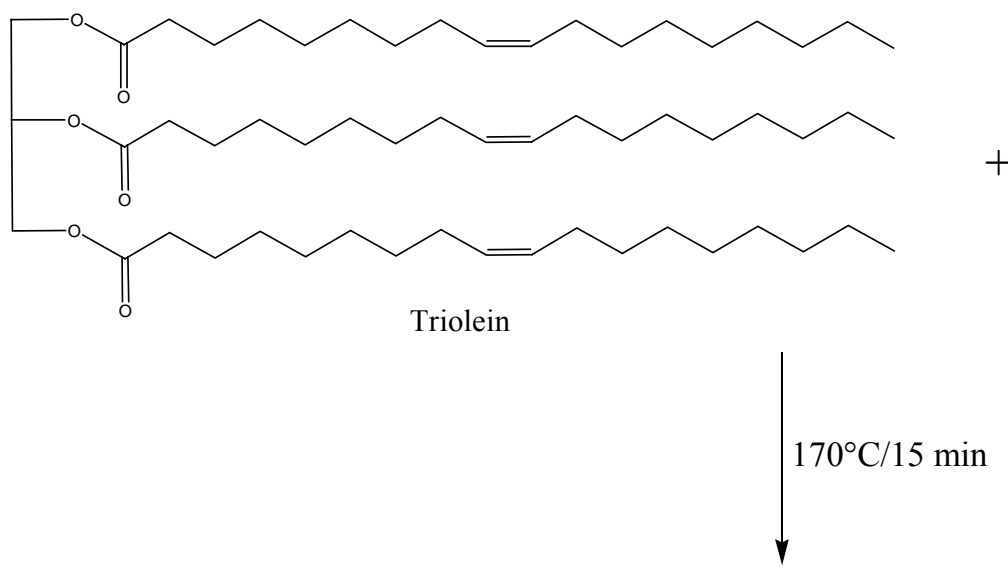

$3 \mathrm{X}$

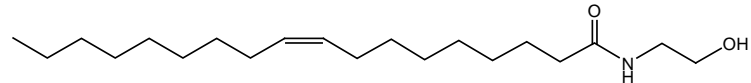

$+$<smiles>[13CH3]C[13C]([135I])(CO)CO</smiles>

Oleoylethanolamide (OEA)

Glycerol 
Version définitive du manuscrit publié dans / Final version of the manuscript published in : Journal of Chromatography A, vol.1202, no.2, 216-219

Fig 2.

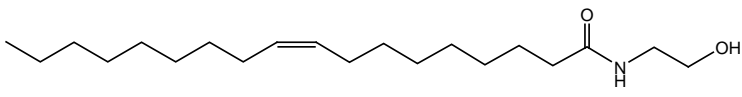

Oleoylethanolamide (OEA)

$\Delta\left(>200^{\circ} \mathrm{C}\right)$

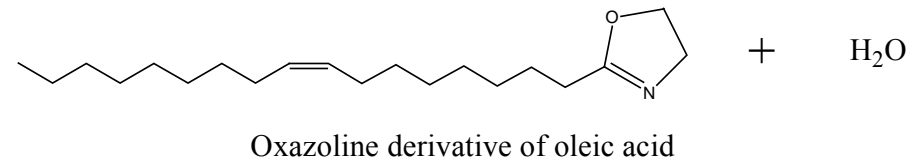




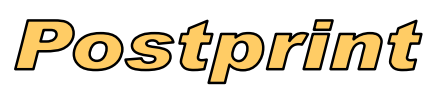

Version définitive du manuscrit publié dans / Final version of the manuscript published in : Journal of Chromatography A, vol.1202, no.2, 216-219

Fig 3.

A

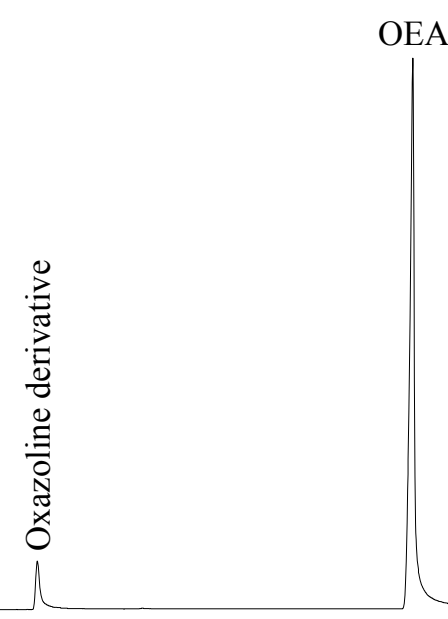

B

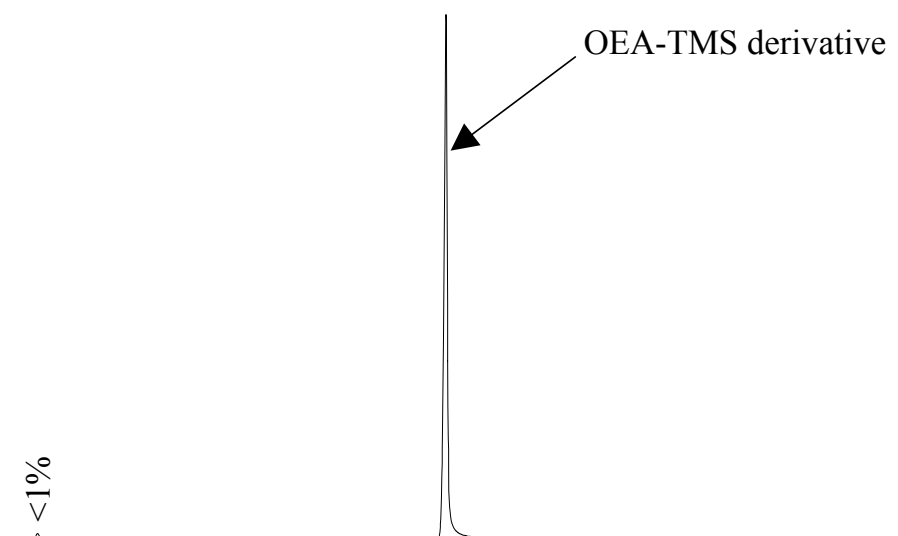




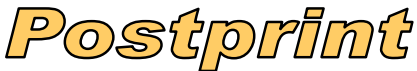

Version définitive du manuscrit publié dans / Final version of the manuscript published in : Journal of Chromatography A, vol.1202, no.2, 216-219

Fig 4.

205

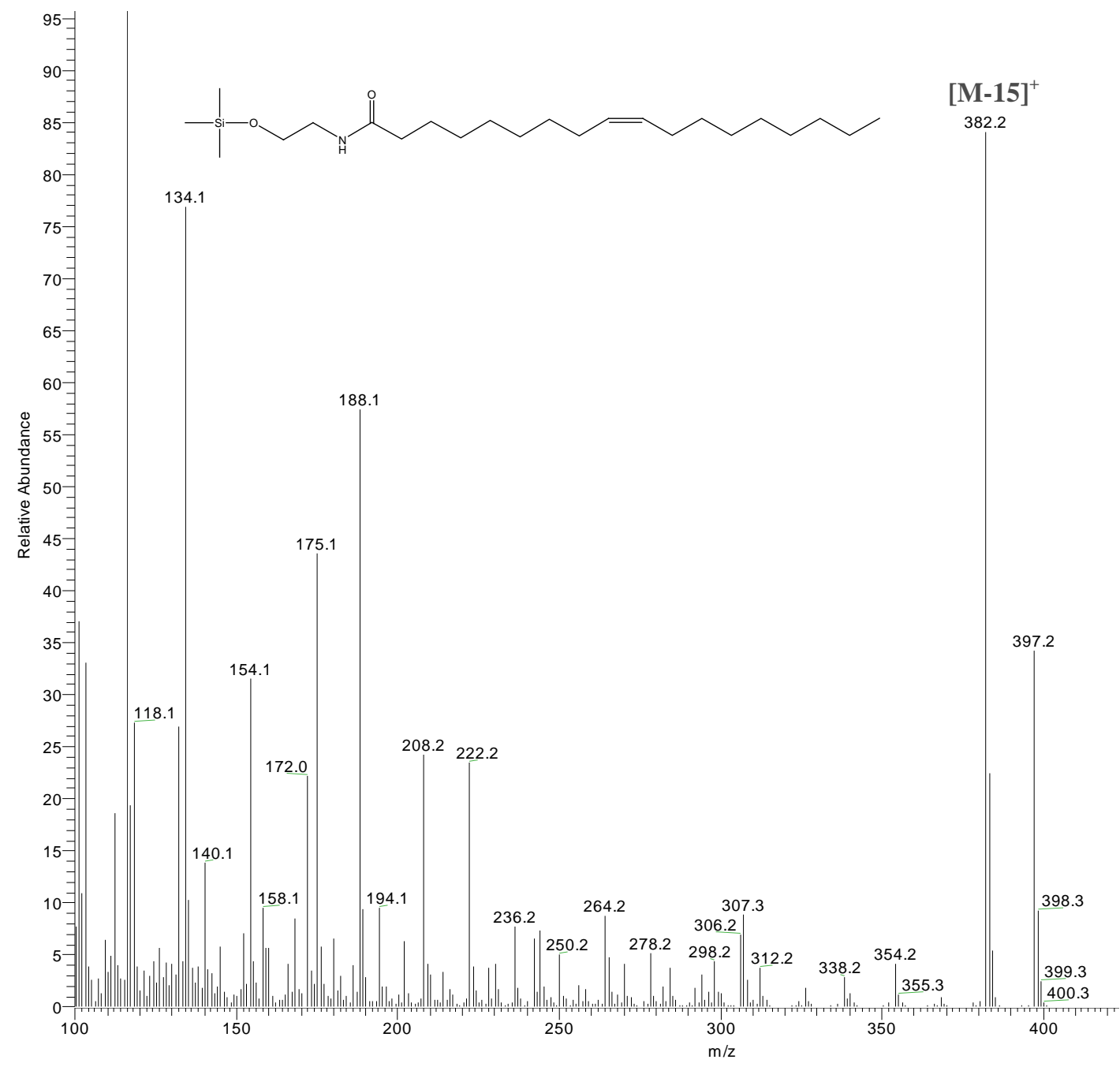

